\title{
Errância e Delírio em Andarilhos de Estrada
}

\author{
José Sterza Justo \\ Euripedes Costa do Nascimento \\ Unesp, Assis
}

\begin{abstract}
Resumo
Os andarilhos freqüentemente caminham pelas estradas sem destino como nômades que renunciam a fixações geográficas, psicológicas e sociais. Não é raro encontrar andarilhos de estrada com manifestações de visões e pensamentos delirantes. O objetivo dessa pesquisa foi investigar possíveis conexões entre a movimentação constante dos andarilhos e a eclosão de delírios. Coletamos e analisamos narrativas de andarilhos, explorando especificamente os conteúdos alusivos à representação de si, de seu mundo e de sua caminhada pelas estradas. Idéias persecutórias, megalomaníacas e depressivas, superinvestidas afetivamente, aparecem com freqüencia nos pensamentos sobre o presente, o passado e nas reflexões sobre os motivos do deslocamento constante. Os resultados sugerem que há uma forte relação entre a movimentação constante e sem destino e as idéias e visões delirantes que os acometem.

Palavra chave: Movimento constante; andarilhos de estrada; pensamento delirante.
\end{abstract}

\section{Wandering and Deliruim in Highway Wanderers}

\begin{abstract}
Wanderers often walk across the highways without destiny, like nomadic that renounce geographical, psychological and social establishments. It is not rare to find wanderers with manifestation of visions and delirious thoughts. We intend to research possible connections between the constant moving of wanderers and the outbreak of the delirious. We collected and analyzed the wanderers' talks, specifically exploring the allusive contents to the representation of themselves, of their world and of their walk across the highways. Persecution, megalomania and depression ideas, super invested of affect, often appeared in their thoughts about present, past and in their reflections about the origins of constant moving. The results suggest that there is a strong relation between constant and without destiny moving and the delirious ideas and visions that emerge inside them.

Keywords: constant moving; wanderers; delirious thoughts.
\end{abstract}

Supermodernidade, modernidade tardia e pós-modernidade. Sejam quais forem os nomes dados à contemporaneidade, inegavelmente vivemos numa época em que a flexibilidade, a pluralidade, a expansão do tempo e do espaço, a realidade virtual, a exigência de movimentação e a incerteza povoam sobejamente o cotidiano do sujeito. O ser humano vive hoje uma condição de desenraizamento sem precedentes que o torna um sujeito circulante, em movimento, seja no espaço geográfico, seja no social e psicológico.

Associado a um complexo conjunto de fatores que modelam o mundo contemporâneo - tais como a globalização, a virtualização da realidade, a aceleração do tempo, a substituição dos espaços fechados (lugares) pelos espaços abertos (não lugares), a dispersão, o desemprego e a pobreza- o fenômeno da errância se expressa com maior radicalidade na figura extrema dos andarilhos de estrada: sujeitos que perambulam sem destino pelas rodovias do país, fazendo da caminhada uma estratégia de sobrevivência (Justo, 1998).

Grande parte dos sujeitos que vivem na condição de andarilhos se desloca pelas rodovias do país à procura de trabalho, principalmente nas colheitas de grãos que, em determinadas regiões, ainda empregam mão-de-obra volante na agricultura. Em situações de extrema necessidade, recorrem à mendicância ou procuram ajuda em instituições filantrópicas das cidades por onde passam.

Entretanto, outra parte dos andarilhos é formada por verdadeiros dromomanes da atualidade: aqueles que já abandonaram todas as

${ }^{1}$ Endereço para correspondência: Departamento de Psicologia Evolutiva, Social e Escolar. Av. Dom Antonio, 2100, 19806 173, Assis, SP. E-mail:sterzajusto@yahoo.com.br perspectivas e sonhos de encontrar trabalho, restabelecer uma familia, ter uma moradia e fixar-se num lugar. $\mathrm{O}$ termo dromamanes é o nome dado aos desertores na época do Ancien Régime, e, em psiquiatria significa mania deambulatória (dromomania). Dentre eles, muitos já estão há bastante tempo "vivendo no trecho", como designam a perambulação pelas estradas, e assumem efetivamente a condição de andarilho e a errância como um modo de vida.

Assim como os dromomanes, desertores do Antigo Regime, os andarilhos da atualidade rompem com toda a malha da rede social, abandonam os lugares de assentamento e sedentarização (família, trabalho, domicílio e tantos outros) e assumem o nomadismo como forma de vida. Tudo o que possuem carregam num saco que levam às costas e mesmo esses pertences mínimos são provisórios e rotativos. Normalmente, levam consigo apenas uma muda de roupa, um plástico para se protegerem da chuva ou forrar o chão para dormir, a "cascuda" (vasilha para colocar a comida que ganham), a "pá" (colher para comer), uma garrafa d'água, eventualmente, também uma de cachaça e alguma outra coisa a mais. Dificilmente portam objetos de valor pessoal como uma lembrança ou mesmo um objeto de uso que possa ter algum sentido especial. Tudo é volátil, efêmero e transitório na vida do andarilho: os objetos que usa, os lugares por onde passa, as pessoas com as quais mantém algum contato e tudo o que está a sua volta. Muitos se desfazem até dos documentos pessoais, considerados inúteis.

A história de vida do andarilho testemunha uma conjugação de várias dificuldades que incidem de forma candente na vida dos mais pobres desalojando-os de nichos sociais. Migrações 
constantes da família (deslocamentos do nordeste para o sudeste, mudanças de regiões ou de propriedades rurais, êxodo do campo para a cidade), baixa escolaridade, desqualificação da mão-deobra, uso abusivo de bebidas alcoólicas, conflitos familiares que incluem a morte dos pais e desentendimentos entre o casal, o desemprego prolongado, a desesperança, a falta de seguridade social, a desfiliação e tantos outros acontecimentos tornam o sedentarismo insuportável, impulsionando o sujeito a buscar na "estrada" alguma chance de minimizar o sofrimento (Castel, 1994, 1995/1998; Jacques, 1998; Justo, 1998; Nascimento \& Justo, 2000; Singer, 1999; Snow \& Anderson, 1992/1998).

Vivendo na situação extrema de isolamento, desassistência, solidão e desamparo, não é raro encontrar casos de andarilhos de estrada com manifestações de persecutoriedade e pensamentos delirantes de si e do mundo, bem como delírios derivados do consumo abusivo de álcool durante muitos anos (Justo, 2000; Snow \& Anderson, 1992/1998). Boa parte desses andarilhos é formada por egressos de hospitais psiquiátricos que foram lançados, larga manu, ao "mundo" pelas políticas de desinstitucionalização estabelecidas para combater o modelo asilar de confinamento da "loucura", vigente até há bem pouco tempo. Porém, também aqueles lançados à errância pela miséria e pelo desemprego acabam expostos à produção de visões e idéias delirantes.

Liberados do confinamento forçado e sem a possibilidade de um reassentamento social mínimo, mediante o resgate de uma moradia, trabalho, dos vínculos familiares, acabaram encontrando na perambulação pelas estradas ou na itinerância de cidade em cidade, a única forma de sobrevivência. Outra parcela dessa população, embora originária dos desalojamentos progressivos do trabalho, moradia, da família e demais vínculos psicossociais, acabou encontrando nos longos anos de errância pelas estradas, apenas a companhia dos próprios delírios. (Justo, 2000, p. 20)

Assim, desfiliados ou deserdados dos nichos sociais e das redes que conectam os indivíduos entre si, provendo uma sustentabilidade e uma ancoragem mínima, os andarilhos acabam movimentando-se a esmo, tanto no plano geográfico, como no psicossocial. A passagem do sedentarismo para o nomadismo, no caso dos andarilhos de estrada, implica fundamentalmente o abandono das referências identitárias fixas e estáveis. Ou seja, ocorre um distanciamento dos referenciais externos e internos, estáveis e perenes, tomados como parâmetro do sujeito e nos quais se mira obtendo o reflexo de sua imagem e o (re)conhecimento contínuo de si mesmo e do seu mundo, possibilitando a vivência de uma continuidade do tempo e uma integração do espaço pela repetição dos acontecimentos do cotidiano.

A perambulação pelas estradas rompe com esse tempo e espaço contínuo e contíguo fazendo aparecer uma realidade interna e externa descontínuas, marcadas pela imprevisibilidade dos acontecimentos emergentes na condição de movimentação constante. As referências externas tornam-se móveis e instáveis e, sobretudo, carente da presença do outro. O que existe à volta do andarilho como espelhamento de sua pessoa e de sua condição de vida são a estrada, o trânsito, as idas e vindas dos veículos, os postos de serviços por onde passa, guaritas de policiais rodoviários, matas, plantações, eventualmente uma casa de moradores da zona rural, animais e tudo o que mais "passa" pelo seu caminho. O "gogó de ema"- saco que carrega às costas - é única coisa fixa em seu cotidiano e que o acompanha diuturnamente. Gogó de ema é uma gíria utilizada pelos andarilhos para designar o saco que carregam. Segundo eles, tal como o papo da ema o saco também comporta qualquer coisa e está sempre sujo.

Diferentemente do que ocorre na vida sedentária, a repetição é quase inexistente na vida do trecheiro. Cada refeição, banho, gole de cachaça, pernoite, e assim por diante, se dá em condições diferentes das anteriores, tornando cada ato de realização de uma necessidade um ato inovador revestido de surpresas e descobertas. O esforço pela sobrevivência acentua-se, ainda, pela labuta individual e solitária. Ele vive, ainda, numa situação de isolamento e rarefação de relacionamentos interpessoais.

A grande referência identitária desses sujeitos é o próprio trecho. Embora carregando a história de vida, as lembranças das experiências vividas, o nome, os marcos da origem e das fundações de sua pessoa e apesar de se reconhecerem por essas ancoragens, o trecho subsiste como referência pessoal mais imediata e sólida. Eles se autodenominam "trecheiros" e se reconhecem e são reconhecidos fundamentalmente por habitarem esse espaço de trânsito.

"Trecho" e "Trecheiro", portanto se confundem. O trecheiro se constitui no "trecho", isto é, na andança, no movimento, no trânsito, no espaço relativamente ilimitado e desprovido de pontos de fixação. As constantes referências que faz às distâncias percorridas denotam a importância para o errante desse espaço vazio que interliga as cidades.

O trecho pode ser o caminho percorrido pelo itinerante por diversas estradas, cidades, estados atravessando fronteiras internas e estrangeiras, até o modo de viver a transitoriedade e o movimento. Pode ser, também, uma alusão à sua casa no sentido de um lugar habitado que, nesse caso, tal como a carapaça de uma tartaruga, acompanha o sujeito por onde quer que vá.

A mobilidade e a volatilidade do universo imediato do andarilho o expõem a uma experiência contínua de estranhamento semelhante à de um viajante, um turista ou de um migrante. A condição de transeunte, passageiro ou estrangeiro retira o chão do sujeito comprometendo seu reconhecimento no território alheio. Segundo Ferreira (1999):

\footnotetext{
Nas experiências de deslocamento, tanto no caso da migração quanto de viagens de turismo, o sujeito pode ver seu espaço subvertido e vivenciar sensações de estranheza e de espanto, chegando à despersonalização psicótica. Ocorre um apagamento do limite entre o real e o imaginário... É tão comum a irrupção de surtos psicóticos em turistas que uma psiquiatra italiana, residente em Florença, chegou a propor uma classificação específica para esse tipo de ocorrência. (pp. 40-41)
}

No nosso meio, além das crises psicóticas agudas incidentes nos migrantes, também são conhecidos os casos dos imigrantes europeus, japoneses e originários de outros continentes que sucumbiram ao estranhamento e à despersonalização enfrentados no choque com a cultura local. A volatilidade do mundo externo e a mobilidade geográfica e social encontram-se associadas inalienavelmente às 
movimentações psicológicas e subjetivas, também elas podendo assumir um caráter errático.

Calligaris (1989), discutindo a estruturação da psicose, pergunta: "O que é a organização de um sujeito estruturado na psicose, mas que nunca entrou numa crise delirante?” (p. 13). E responde:

É um sujeito eminentemente errante, errante no sentido da errância não do erro. ... Trata-se de um horizonte de significações que não é organizado ao redor de uma significação central que organizaria todas as outras. E, como conseqüência dessa posição, o sujeito tem que errar. Mas errar não na procura de algo que poderia ser encontrado como significação final, nada disso. Isso seria mais o 'erro neurótico' do que o 'errar psicótico'. Errar porque não existe um lugar a partir do qual podemos medir a significação do que estamos fazendo. Nesta medida é evidente que a única coisa que resta é percorrer todos os caminhos. (p. 13)

O andarilho, psicótico ou não, parece estar constituído nessa estrutura de ausência de um eixo central organizador de sua vida, de suas buscas no plano afetivo, social ou econômico. Não está orientado para objetivos, finalidades e nem articula os sentidos de suas ações e realizações a algo que possa organizar e dar alguma significação geral a seus atos de rotina. Parece viver, efetivamente, essa condição de fluidez e errância tanto no plano externo como no interno. Não erra apenas no plano geográfico, mas através do delírio, erra no plano psicológico exatamente para não possibilitar o conhecimento e o conseqüente questionamento e controle de suas crenças pelos outros, o que seria inevitável em relacionamentos intensos e próximos. $\mathrm{O}$ psicótico e o andarilho talvez se refugiem em suas idéias e delírios para manterem, com a solidão, a sua crença.

O delírio, assim como todo sintoma, pode ser compreendido como uma manifestação do inconsciente do sujeito e um modo de realização de desejos, além de ter uma função restauradora do mundo, num esforço para reconstruir um cenário em que os objetos possam ressurgir e serem reinvestidos, objetos estes que foram, através do recalcamento, abandonados pela libido desligada das coisas e das pessoas anteriormente amadas. $\mathrm{Na}$ psiquiatria clássica, o delírio é tomado, de maneira geral, como desvarios ou idéias absurdas, falsificações da realidade ou alterações do juízo produzidas por desvios do pensamento presentes nas psicoses do tipo paranóide e parafrênica (Melo, 1979). Etimologicamente, a palavra delírio surgiu da contração do prefixo "de" que significa "fora" com o radical "liros" que significa "sulcos", designando aquilo que foge ou escapa a um assentamento, a um centro ou a um caminho sulcado na terra.

A psicopatologia clássica, portanto, irá apropriar-se desse termo para designar idéias, representações, intuições e percepções que fogem à lógica dominante ou ao pensamento sulcado em caminhos associativos e relacionais fundados em leis e princípios de raciocínio hegemônicos. O delírio teria como características principais: a) uma convicção profunda do sujeito de suas percepções, idéias, pensamentos e pressentimentos tomados subjetivamente como fatos inquestionáveis; b) a invulnerabilidade a qualquer ocorrência que possa contrariar as idéias cristalizadas ou os dinamismos associativos do delírio tornando-o bastante resistente a modificações.
Com essas características básicas, o delírio pode se apresentar em diferentes graus de intensidade e acompanhar desde as psicoses agudas até pensamentos gestados em funcionamentos psicológicos menos abrangentes e localizados em certas áreas ou esferas da atividade do sujeito. Por exemplo, o sectarismo e o fanatismo são expressões de idéias sobrevalentes que produzem adesão e confirmação incondicionais, portanto, podendo ser tomados como manifestações de um pensamento deliróide. Nas psicoses agudas, o delírio acompanha uma mudança geral do funcionamento psicológico e das experiências do sujeito marcadas por sensações de estranhamento de si e das situações que o rodeiam. Normalmente, a irrupção do estado psicótico é permeada por sensações ou pressentimentos de que algo intempestivo e estranho está por acontecer e por sensações de esvaziamento do Eu que abrirão espaço para o aparecimento de idéias delirantes, chegando ao ponto de o sujeito sentir-se invadido ou possuído por forças ou entidades sobrenaturais.

Nos estados psicóticos mais agudos, as significações, as sensações e as percepções são dominadas pelo delírio. Tudo é percebido e decodificado em função do delírio comandado pelo funcionamento psicótico marcado fundamentalmente pela diluição dos limites entre o Eu e o não Eu. Nas situações mais extremas, o delírio ocorre sem qualquer desencadeante identificável. Não há qualquer fato ou acontecimento externo desencadeador das idéias delirantes. Enquanto nas formações ideativas deliróides há uma ocorrência sobre a qual a sobrevalorização afetiva amplifica sua importância e fustiga interpretações e fabulações, no delírio radical os pensamentos irrompem sem qualquer motivação explícita.

O delírio opera, fundamentalmente, no plano relacional da cognição, produzindo conexões autônomas entre os dados da percepção, sem a preocupação em testá-las na realidade e verificá-las, criticamente, mediante o rastreamento do percurso cogitativo realizado ou pela prospecção de outras conexões possíveis. Dessa forma, afeta a intuição criando pressentimentos e convicções indemolíveis; age na imaginação, criando fabulações, alucinações de memória e imagens fantásticas; interfere no pensamento e na interpretação dos fatos e acontecimentos, criando relações inusuais entre dados da percepção em si apreendidos sem deformações; atinge a percepção, criando imagens distorcidas, amplificadas ou endógenas, sem qualquer referência a objetos externos.

A psiquiatria clássica identifica, ainda, alguns temas típicos das visadas delirantes. Alguns conteúdos remetem-se ao modo como o acontecimento delirante é vivido, tais como as temáticas persecutórias, as temáticas de prejuízo - onde o sujeito é subestimado e se vê como objeto de zombarias e desprezo- e as temáticas que abordam a influenciabilidade, quando o sujeito sente-se possuído, dominado por forças malignas e comandado por fenômenos estranhos. Outro grupo temático diz respeito à maneira como o sujeito concebe a relação Eu-mundo. Nesse grupo, predominam os delírios de grandeza e de aniquilamento do Eu.

Interessa-nos, particularmente, enfatizar no delírio o intenso investimento de certas idéias, sua potência fabuladora, imaginativa e 
interpretativa, seu caráter errático e errante no sentido de fugir das convencionalidades cognitivas estabelecidas, sua capacidade de fazer o pensamento percorrer caminhos inusuais e realizar conexões extravagantes e absurdas e, ainda, sua função restauradora, ou seja, sua tentativa de recompor o sujeito no cenário do seu mundo.

Partindo destas considerações, o presente artigo, derivado de pesquisa baseada em estudo de caso, tem como objetivo apresentar, analisar e discutir as narrativas delirantes vivenciadas por andarilhos de estrada, procurando demonstrar conexões entre a produção delirante e a condição de errância na contemporaneidade.

\section{Método}

Tais narrativas foram obtidas através de entrevistas realizadas nas rodovias das cercanias da cidade de Assis, São Paulo, e no Cetrem (Centro de Triagem e Encaminhamento do Migrante) dessa mesma cidade. Tal entidade assistencial é mantida pela prefeitura municipal e é responsável pelo recolhimento de toda população migrante que passa pela cidade: mendigos, moradores de rua, itinerantes em busca de trabalho, trecheiros e andarilhos.

As entrevistas semi-estruturadas procuravam focalizar a história de vida do sujeito tentando percorrer os fatos e acontecimentos que foram mais significativos para ele, sua compreensão dos motivos que o levaram a romper com o sedentarismo e sua compreensão dos sentidos da errância ou da vida no "trecho".

No Cetrem, apesar da curta permanência dos sujeitos nesse local, foi possível realizar as entrevistas numa situação bastante favorável. Tendo-nos sido cedida uma sala isolada; pudemos estabelecer contatos preliminares expondo os objetivos do trabalho, propondo o "contrato" e realizando uma primeira escuta das demandas do sujeito; fizemos retornos em função das necessidades da pesquisa ou de demandas do sujeito surgidas ao longo das sessões de entrevista. Tudo isso, tornou possível a constituição de relacionamentos marcados pela compreensão da natureza do encontro, pelo senso de compromisso e responsabilidade com o acordo estabelecido e pela confiança entre as partes.

As entrevistas realizadas nas estradas tiveram um enquadramento bem diferente, o que não significa perda de qualidade ou de confiabilidade nos dados obtidos. Nesse caso, o procedimento foi modelado conforme as condições em que vivem os andarilhos, ou seja, adotou-se a imprevisibilidade, a movimentação e a instantaneidade como forma de acesso aos sujeitos e ao seu universo. Portanto, ao longo de percursos realizados pelo pesquisador nas rodovias da região de Assis, São Paulo, foram abordados aqueles andarilhos avistados nos acostamentos.

Observando-se as normas ético-científicas para a realização de pesquisa com seres humanos, procurou-se no início da abordagem esclarecer os motivos daquele contato repentino e estabelecer um diálogo cordial capaz de diminuir o máximo possível as ansiedades inevitavelmente emergentes nessa situação tanto no pesquisador quanto no andarilho pego de surpresa pela aproximação inusitada de um estranho. Alguns se recusaram ao contato e ao diálogo, prosseguindo em sua caminhada e outros, a maioria, acedeu ao convite dispondo-se, inclusive, a sentar-se à sombra de alguma árvore ou em algum outro recanto um pouco mais recuado da pista e mais confortável, mostrando-se bastante à vontade e até contente com a nossa presença.

Evidentemente que, nessas condições, as entrevistas se restringiram a um único contato, tornando impossível o estabelecimento de um rapport mais efetivo e a retomada posterior para aprofundamentos ou esclarecimentos de alguma fala ou assunto. Apesar dessas limitações, o contato com os andarilhos na estrada oferece outras vantagens. Ocorre no "território" do sujeito, num momento em que está vivendo plena e intensamente sua condição de errante e insere minimamente o pesquisador nessa condição, permitindo-lhe um contato direto, ainda que breve, com alguns aspectos desse cotidiano: os ruídos do tráfego da rodovia, o impacto do vento produzido pela passagem dos veículos, a sensação de medo e insegurança provocados pela velocidade e proximidade dos veículos, a sensação de infinitude e aridez da estrada, a solidão expressa no despovoamento das terras contíguas ao acostamento completamente vazio e tantas outras sensações provocadas por esse lugar.

Para assegurar a privacidade e o sigilo das informações fornecidas pelos sujeitos, foram utilizados pseudônimos. Vale destacar, ainda, que o roteiro de entrevistas segue a resolução 196/96 sobre pesquisas envolvendo seres humanos do Ministério da Saúde (1996), sendo sua aprovação emitida pelo Comitê de Ética em Pesquisa da Faculdade de Medicina de Marília, SP.

\section{Resultados e Discussão}

\section{Caso 1: Uma História Delirante}

Messias. Messias é um rapaz de 36 anos e já está no trecho há 19 anos. Quando o encontramos no Cetrem, estava com a perna direita engessada devido a um acidente que sofreu na noite anterior na rodovia Raposo Tavares (SP-270) rumo à cidade de Presidente Prudente, São Paulo. Nessa ocasião, nos disse que foram as "forças maiores" que tentaram matá-lo, fazendo referência aos policiais militares que, segundo ele, o estavam perseguindo há muito tempo, desde a época em que resolveu abandonar o lar. Conta que teve uma infância conflituosa após o "sumiço" do pai que, segundo ele, fora raptado pelos policiais durante o regime militar. A partir de então, resolveu abandonar o lar e optou, no início, por um estilo de vida alternativo, se tornando um hippie durante 5 anos. Nesse período menciona que, além de fazer uso de maconha élcool, havia cometido muitos pecados e que decidiu se tornar um andarilho para pagar esses pecados com Deus e também para tentar encontrar seu pai que havia desaparecido há muitos anos, conforme podemos verificar em seu próprio relato:

Bem, antes de começar no trecho, eu era um artesão profissional... porque eu acho que um hippie que faz o seu trabalho... ele não tá agindo corretamente com Deus porque... tirava o dinheirinho daquela senhora que ia comprar um litro de leite pro seu filhinho... isso aí foi doendo meu coração, e um dia eu falei com Deus que eu não ia fazer esse tipo de pecado, que eu ia renunciar eiria sair pelo trecho, caminhando pra pagaros meus pecados daquilo que estava fazendo nas minha transgressão, nas minhas maldade, por aquele hippie que fumava maconha... e um dia eu 
falei com Deus, dentro de meu ser, né, e falei: "olha Deus, eu vou andar pelo mundo, pelas estradas, por esses asfaltos, por essas linha de trem com o propósito... eu tinha perdido era meu pai em 1979, até um dia eu encontrar ele porque ele saiu de casa, foi para uma penitenciária... e eu já sabia das coisas que acontecia dentro da Polícia Militar, que ele sumia com as pessoas e dava notícias daquelas pessoas que tinha morrido". Eu saí pelo mundo, um andarilho me tornei aí, na finalidade de encontrar meu pai... e pagar os meus pecados daquela vida do passado, do hippie, daquele que tirava talvez um prato de comida da boca de uma criança pra gastar com maconha, com álcool, em coisas soberbas. Então por causa disso hoje eu prefiro ficar na classe dos andarilho.

Messias também nos conta sobre seus sentimentos ambivalentes com sua mãe, renunciando ao seu amor por ela devido ao desaparecimento do pai. Ele nos revela que é difícil compartilhar seu amor somente com a mãe, pois, para ele isso só seria possível na presença do pai. Desconfiado das histórias que lhe contaram quando criança sobre o paradeiro de seu pai, passou a duvidar das explicações fornecidas pelos policiais militares e decidiu investigar essa história pessoalmente no caminhar pelas estradas, levando, inclusive, mensagens divinas por onde passa:

... a minha mãe é uma grande senhora, dona de si, mas pela morte de meu pai e o meu amor que tinha perante os dois até os 17 anos, eu achei que não adiantava ficar com minha mãe, dando amor para minha mãe, sabendo que meu pai eu iria descobrir pra ver se tava morto ainda. Porque aquelas histórias de ter morrido numa cerca de arame, de um raio, pelos delegados, passou por todos eles, mas dentro do meu coração, não, então eu sabendo disso pra não dar o amor, que eu sempre queria dar o amor meu para meu pai, minha mãe, eu resolvi não dar mais para nenhum dos dois mais... Se me pai morreu, eu achei que minha mãe não merecia meu amor... mas eu também cheguei um ponto de tanto sofrer no mundo, que para mim não dava êxito e então estou aí na estrada procurando meu pai pra mostrar pros policiais que eles estavam enganados, que ele tá vivo morando em alguma mata por aí e eu vou achar ele, se Deus quiser porque dentro do trecho, eu dizendo pra você que a única coisa que temos que respeitar é Deus. Deus e os superiores, as autoridades das forças maiores e não se levar por espíritos malignos, perversos que existem na face dessa Terra... um dia todos nós vamos morrer e nós não sabemos nada desse mundo... hoje eu tento pregar a palavra de Deus.

Decididamente, o ápice da narrativa de Messias é apresentado a seguir quando compara a vida de andarilho com a caminhada de Jesus para o Calvário, associando o sofrimento da estrada carregando um saco às costas com o peso da cruz conduzida pelo próprio Cristo. Neste instante do relato, merece destaque um trecho onde declara almejar ser o próprio Deus de uma nação:

A vida do andarilho, cara, por essa miséria, esse sofrimento é igual à vida que Jesus teve na Terra pra salvar a humanidade dos pecados. Cê vê, a gente carrega esse saco com um cobertor, uma lona de plástico pra se abrigar da chuva... às vezes é um peso que parece a cruz que Jesus carregou... que agora nós estamos na quaresma, depois vem a crucificação dele. Eu tenho um imprevisto de ter um ano mais repleto... porque 2000 não passará, não chegará, é a morte... O trecheiro é isso: de repente, ele pode se tornar um Deus... por acaso, eles falam que vão passar pelos asfaltos e os carros não vai pegar, eles se jogam na frente do asfalto, o carro não pega ele, certo? Ele passa, ele vai começando a ter a comunicação com Deus, cara, ele vai evoluindo pra Deus e Deus vai se manifestando nele... Um dia, eu espero ser Deus, um dia espero sobreviver, e no dia da minha morte, todas as pessoas que me ajudaram nesses 18 anos no trecho, eu calculo mais ou menos umas 40.000 (sic), umas 50.000 pessoas que já me ajudaram, a minha família é 10 , mas disso se tornou a minha família em 50.000 (sic) é a multiplicação. Já posso chamar uma nação, e eu andando pelo mundo, um dia eu posso ser um Deus dessa nação, e livrar a humanidade dos pecado, só isso.

O conteúdo dessa fala é uma amostra exemplar de idéias delirantes despertadas na trajetória e nas condições de vida em que se configuram os andarilhos de estrada. Embora muitas condutas de andarilhos possam ser qualificadas como esquisitas, bizarras ou até mesmo desviantes, nesse caso, é nítido o dinamismo que percorre essa fala, produzindo imagens e interpretações delirantes. São nítidas, também, as associações feitas pelo próprio sujeito entre sua condição de andarilho, de errante, e os sentidos que atribui a sua presença no mundo.

A culpabilização é um dinamismo bastante forte e presente nas subjetivações desse andarilho. Aparece em sua fala de forma explícita, quando se responsabiliza por danos ou prejuízos que julga ter causado a outros, vendendo bijuterias como hippie e, implicitamente, quando se refere ao seu desinvestimento afetivo da figura materna por entender que não poderia "trair" o pai ou colocá-lo num segundo plano por não poder destinar parte de seu amor a ele em função de sua ausência.

A busca do pai, a procura incansável dessa figura desaparecida enigmaticamente, segundo a compreensão dele próprio, alude a uma experiência depressiva vivida intensamente como perda da figura paterna altamente investida de afetos. Esse pai desaparecido, ausente, também é simbolizado na figura de Deus em quem disse ter encontrado o "caminho" da redenção dos pecados, tomado como o sentido principal de sua vida como andarilho. Conforme suas palavras, precisa caminhar pelo mundo para encontrar seu pai, pagar seus pecados e quem sabe, um dia, transformar-se num Deus e ajudar a humanidade a se redimir.

A megalomania e a inflação narcísica do Eu também são formações bastante comuns nos delírios dos andarilhos. Como nesse caso, muitos se atribuem missões grandiosas, salvadoras da humanidade e entendem suas caminhadas como forma de realização desse desígnio. É freqüente, ainda, dentro do dinamismo de exaltação e superpotencialização de si, imaginarem-se como seres indestrutíveis tal como Messias fala de andarilhos que alcançam a divindade e a imortalidade podendo, inclusive, se lançarem à frente dos veículos em pleno trânsito das estradas. Vale destacar, neste caso, que encontramos Messias com uma das pernas engessadas por ocasião de um atropelamento sofrido na noite anterior numa rodovia de bastante movimento no perímetro urbano da cidade de Assis-SP.

Um certo grau de persecutoriedade também é comumente encontrado nas visões de mundo dos andarilhos. Sentem-se ameaçados por inimigos ou forças malignas que atentam contra sua pessoa ou sua missão. $\mathrm{Na}$ fala de Messias, a persecutoriedade aparece sob a forma de desconfiança na versão da polícia sobre a morte de seu pai e na crença em "espíritos malignos perversos que existem na face da terra".

De maneira geral, a lógica do andarilho delirante é muito semelhante à lógica da paranóia comandada pela amplificação narcísica do Eu, projetividade, persecutoriedade, megalomania e 
por interpretações que resultam em narrativas de estilo épico caracteristicamente desenvolvido em torno de feitos heróicos de um personagem central capaz de desafiar e vencer os mais temíveis perigos em prol da coletividade.

Dentro dessa "lógica" delirante, o caso de Messias se distingue de outros andarilhos não delirantes por produzir uma narrativa tão singular que o diferencia, também, pelas estratégias de sobrevivência utilizadas na estrada. Em sua labuta cotidiana, parece que essa condição de vida, permeada por sofrimento, desmazelo e situações extremamente precárias, tem pouca ou quase nenhuma importância para ele. Tudo é compensado por seu sonho de se tornar um Deus e poder realizar a gloriosa missão de "salvar" a humanidade dos pecados. A perambulação constante e todas as demais condições objetivas que acompanham sua existência são assimiladas e justificadas como parte de seu processo vital e de seu projeto de vida.

A fluidez que permeia seus "delírios", dada pela ampla possibilidade de estabelecer nexos associativos entre as imagens e as percepções que brotam do seu presente e das recordações de seu passado, parece lhe proporcionar um certo sentido de vida aparentemente indolor em que a lógica da realidade é rarefeita e desconsiderada de impressões do cotidiano. A função restauradora do delírio, nesse caso, fornece generosas compensações para as percepções e vivências das condições de pobreza extrema e dos sofrimentos deflagrados por conflitos emocionais e afetivos ocorridos nas relações familiais. As perdas dos vínculos com a família são compensadas, tal como transparece em sua fala, pela multiplicação de seus relacionamentos hoje beirando a cifra de 40 ou 50 mil pessoas, segundo seus cálculos, que o ajudaram e que agora toma como sua grande família. A compensação maior de toda situação de paupéria e sofrimento, vivida no passado e no presente, é dada pela sua expectativa de transformar-se em Deus dessa nação que julga estar criando em torno de si. A pobreza, o sofrimento e a condição de errante são transformados em vantagens ou dádivas que permitem sua ascensão ao topo maior das aspirações humanas: um lugar ao lado de Deus.

Messias parece viver sua errância de maneira "livre e desimpedida" por não estar inserido nas armadilhas da fixação social que pode, às vezes, aprisionar o sujeito e impedi-lo, assim, de desfrutar a autonomia que a transitoriedade nos espaços abertos pode tornar factível, pelo menos no plano geográfico. A transformação de uma identidade fincada no sedentarismo, vinculada a imagens de estagnação, em uma identidade calcada no nomadismo, vinculada a imagens de movimentação, permite uma maior expansão e mutabilidade das representações de si mesmo e do seu mundo favorecendo restaurações, compensações e racionalizações sobre as condições de vida. Seja como for a maneira do andarilho viver e entender sua deambulação pelas estradas, é necessário ponderar que a errância se coloca como uma condição peculiar da contemporaneidade em que a circulação no imprevisível, provisório e inesperado, parece proporcionar, senão uma narrativa delirante, pelo menos, um contato anônimo entre o indivíduo e a heterogeneidade.
A crença de Messias de que as agruras de sua vida na errância serão recompensadas pela sua beatificação é semelhante à da pessoa comum que também acredita que seus sofrimentos são provações divinas para o acesso ao paraíso celestial. Coloca-se aqui a tênue diferença entre um delírio psicótico propriamente dito e uma idéia deliróide: ambos assumem um caráter sobrevalente no plano afetivo e cognitivo fornecendo recursos psicológicos para racionalizações apaziguadoras dos conflitos emergentes nas subjetivações. $\mathrm{O}$ traço distinto entre ambos é a intensidade da sobrevalência afetivo-ideativo das crenças estabelecidas e a abrangência de suas visadas. Messias vive intensamente uma crença no seu devir beato, fazendo gravitar todo seu cotidiano e todo o sentido de sua vida em torno desse acontecimento.

\section{Caso 2: Delírio Associado ao Abuso de Álcool}

Dionísio. Dionísio é um rapaz de 41 anos de idade e perambula pelas rodovias há 11 anos. Sua história de vida é permeada por conflitos no núcleo familiar desde a morte de seu pai, quando contava com 8 anos de idade. Após a morte do pai, a família emigrou para a cidade de São Paulo em busca de melhores oportunidades de trabalho. Dionísio nos conta que nesse período era maltratado pela mãe que o prendia no banheiro de casa e que, entre um conflito e outro, acabou internado num orfanato aos 9 anos de idade. Após esses episódios marcantes, foi morar com uma das irmãs até a idade de 20 anos quando casou e teve um filho desse relacionamento que durou apenas 1 ano. Ele relata que nessa época fazia uso pesado de bebidas alcoólicas e pressionado a arcar com o ônus da vida sedentária, como o pagamento de aluguel, despesas domésticas, o vestuário e tantas outras responsabilidades, resolveu abandonar esse estilo de vida sedentário e perambular sem destino pelas estradas:

Ela [esposa] simplesmente não conseguiu se desprender da família dela, me pressionava o dia inteiro, me xingava, que eu só queria beber e acabou, levou meu filho embora... aí resolvi sair pela estrada pra buscar um trabalho e tô assim até hoje... às vezes faço um bico [trabalho temporário] num lugar e outro, mas a bebida sempre presente... me isolava... quando começo a passar dificuldade ou que alguém me humilha, a gente passa muita humilhação andando por aí... então que se dane, eu vou beber mesmo, eu quero beber pra sair fora do ar, eu quero sair da realidade... porque quando a gente olha a coisa, a situação cruel da maneira que tá, é difícil cê conviver com isso...

Dionísio aos poucos vai nos contando de suas vivências em torno do uso da bebida na estrada, narrando de maneira truncada acontecimentos fantásticos que ora se confundem com a realidade, ora se apresentam de forma exorbitante, deixando dúvidas quanto ao grau de fabulação existente nessa trama delirante. Narra a facilidade para conseguir bebida e que sem ela, começa a "sofrer dos nervos". Após o consumo pesado de álcool por longos períodos, Dionísio nos conta que viveu histórias alucinantes como a do "elefante branco" que julga ter encontrado várias vezes na estrada, interceptando seu caminho, perseguindo-o, além, ainda, de nos relatar sua peleja com as baratas que não cansa de pisotear pelos acostamentos das rodovias: 
... já que é assim, não resolve fugir dele... Ele quer te pegar, mas cê é mais esperto, entra no mato, se esconde... o elefante branco, cê tem que sair correndo senão ele te pega e te leva, mata... então o que acontece? Eu agüentei 42 dias! Quando passa os primeiros 20 dias, me ataca os nervos de uma maneira que eu começo a maltratar as pessoas... não é que eu sou agressivo, mas parece que é a falta de álcool no sangue... que nem eu tô aqui [Cetrem] pra ver se consigo um sapato, ou um chinelo que seja... meus pé tá cansado de pisar nesses bichos... baratas, vermes de todo os lados onde cê vai tem eles... eles brota do chão igual água e cê tem que passar, não tem jeito, não tem outro caminho, cê tem que seguir em frente... uma vez tive internado num hospital de louco, eu já passei uma experiência, 04 meses foi uma maravilha, 04 meses saí de lá, fugi, sendo que era pra ficar mais tempo... com 09 meses eu voltei a beber e depois disso desandei... eu tenho pavor, tenho medo de passar o que passei...

O relato de Dionísio expõe uma trajetória de vida bastante comum entre os andarilhos. Migração da família, vivência intensa da penúria, sofrimentos e abandono na infância, desavenças no relacionamento com a mulher e alcoolismo. $\mathrm{O}$ uso de bebidas alcoólicas invariavelmente é justificado como um poderoso sedativo para os sofrimentos vividos tanto no sedentarismo como na errância, um meio de esquecer o passado, como muitos afirmam ou de "sair fora do ar... sair da realidade", como enfatiza Dionísio. Freqüentemente, os andarilhos mencionam em suas histórias de vida que o uso de bebidas alcoólicas marcou profundamente o ápice da crise que culminou com sua deserção da vida sedentária. Mencionam também que a bebida ajuda a suportar as adversidades e a solidão da condição de errantes (Nascimento \& Justo, 2000).

Embora o alcoolismo e o uso abusivo de outras drogas possam ter como pano de fundo um quadro de dependência fortemente enraizado na estrutura psicológica do sujeito, a fronteira entre o uso autônomo e o uso dependente do álcool não é sempre fácil de discernir, especialmente entre os andarilhos de estrada. Seja como for, o fato é que Dionísio se declara dependente de bebidas alcoólicas e toma seus pensamentos, mergulha neles, com um enorme senso de realismo. Os inusitados episódios dos "vermes que brotam do chão" e a história do "elefante branco" podem ser tomados como uma produção delirante de seu pensamento, mas, obviamente, isso não quer dizer que seja uma idéia ou uma imagem desconexa, arbitrária e desprovida de sentido ou de inteligibilidade. Pela experiência que acumulamos no tato com o universo dos andarilhos e sabendo do temor que têm da aproximação de ambulâncias ou de Kombis brancas utilizadas para recolhê-los forçadamente a instituições filantrópicas ou a hospitais psiquiátricos, não descartaríamos a possibilidade dessa imagem do "elefante branco" estar metaforicamente aludindo a um desses temíveis veículos ou também a veículos pesados, como caminhões, carretas e ônibus que também representam uma grande ameaça.

Sua narrativa denota um sentimento de persecutoriedade muito intenso associado ao uso abusivo do álcool, às dificuldades e frustrações vivenciadas no núcleo familiar originário e às incertezas e instabilidades que permeiam sua atual condição errante. Solto na estrada, Dionísio parece seguir seu caminho adiante, mesmo tendo que enfrentar seus "monstros" interiores em suas intermináveis jornadas e a cada experiência etilica. Nesse sentido, a vida errante parece propiciar, pelo menos, a liberdade para o sujeito vivenciar seus delírios sem o incômodo e as constrições de qualquer regime de confinamento e disciplina.

Dionísio fala das transmutações repentinas de sua pessoa, de oscilações de seu estado de espírito, que se refletem em sua disposição para beber ou no trato com outras pessoas atribuindo-as ao efeito do uso do álcool ou da abstinência. Considera sua deserção para o "trecho" como conseqüência da insuportabilidade da convivência com a mulher e dos atritos e discórdias constantes associados ao uso de álcool e ao desemprego. Parece um fugitivo tentando se livrar ou se distanciar de tudo o que sente como ameaçador ou causa de sofrimento: a mulher, o elefante branco, as baratas, as humilhações...

Mesmo sendo potencializados pela abstinência alcoólica, os conteúdos de seus delírios denotam um estado de perseguição que, embora assumindo uma dinâmica paranóide, não deixam de aludir a uma condição objetiva de existência marcada pela vitimização do desemprego e da miséria. Denunciam, portanto, seu embate com tantos "elefantes" que ameaçam esmagá-lo e sua condição de ter que "correr" ou fugir para sobreviver. Seus delírios funcionam como metáforas através das quais expressa os sentimentos de hostilidade e a rejeição, presentes nas matrizes de seus relacionamentos e nas fundações de sua deambulação.

\section{Caso 3. Sr. Felipe e um Delirio Megalomaníaco}

Sr. Felipe. Sr. Felipe foi um dos casos de andarilhos que encontramos e entrevistamos no acostamento de rodovias. Com ele tivemos a oportunidade de realizar três entrevistas por ter permanecido cerca de uma semana acampado nas proximidades da cidade de Marilia, situada na região oeste do Estado de São Paulo. A primeira entrevista foi realizada enquanto estava se aproximando dessa cidade, na rodovia SP 333, e as demais ocorreram junto à barraca que montou à beira dessa rodovia já nas imediações do trevo de acesso à zona urbana.

Diferentemente da maioria dos trecheiros, o Sr. Felipe levava consigo um carrinho, ou melhor, uma casa ambulante e um cachorro que o acompanhava: um fiel amigo que, dizia, havia salvado sua vida algumas vezes. $\mathrm{O}$ carrinho que puxava pelo acostamento era bastante precário feito com uma estrutura metálica assentada sobre duas rodas pequenas e madeiras que formavam o caixote onde transportava seus pertences e provimentos. $\mathrm{O}$ acampamento que montou à beira da rodovia era relativamente bem equipado, embora muito tosco e simples.

Armou uma barraca utilizando um pedaço de lona plástica preta sustentada por pedaços de madeira e improvisou uma mesa com pedaços de tábua dispostos como tampão e pedaços de caibros utilizados como pés de sustentação. $\mathrm{Na}$ barraca havia um colchonete, sacolas de plástico e sacos com roupas e mantimentos e um pequeno fogão improvisado com pedaços de tijolos. Sobre a mesa arranjada do lado de fora havia latas, panelas e canecas velhas, recipientes de plástico, pratos, talheres e, curiosamente, várias revistas e folhas de jornal. Posteriormente, ficamos sabendo que esse senhor gostava de ler, guardava certos recortes de jornal, especialmente aqueles que traziam reportagens 
e matérias sobre sua aventura, feitas por repórteres das cidades por onde passava interessados em sua epopéia.

Nascido na Argentina e falando uma mistura de português com espanhol, tinha aproximadamente 55 anos de idade, era bastante receptivo ao contato, falava com eloqüência e ficava à vontade, às vezes, dando gargalhadas. Seu olhar era fugidio, dificilmente fixava-se no interlocutor e possuía dois tiques nervosos que ocorriam com bastante freqüência. Num deles, repentinamente, esfregava freneticamente os dedos na palma de uma das mãos dizendo rapidamente: "plata, plata, plata, cuatro puntus cardinales". No outro, coçava o canto de um dos olhos dizendo: "Sacaran... mi ojo isquierdo". Quanto ao primeiro tique, quando o indagamos sobre o significado daquele gesto, disse que o mundo estava dominado pelo dinheiro e que essa era a origem dos conflitos entre as nações. Sabemos tratar-se de um gesto antigo que, segundo a crença popular, tem o poder de atrair dinheiro. Quanto ao segundo, nos contou que, ainda quando morava na Argentina, teria sido vítima de uma bala disparada por um assaltante perseguido por policiais no interior de um ônibus urbano. Porém, havia se recuperado desse acidente com a ajuda do sol e da lua tidos por ele como seus guardiões.

Conta que sua vida foi marcada por longas andanças. Partiu da Argentina em um navio e desembarcou em Paranaguá, Paraná, daí seguindo a pé por várias cidades como Curitiba, ainda no Paraná, Santos, em São Paulo e Porto Alegre, no Rio Grande do Sul. Em todas as entrevistas respondia prontamente às nossas perguntas, porém, logo começava a deslizar sobre seus delírios acrescentando comentários e relatos de acontecimentos e façanhas bem distantes do que havia sido perguntado e do assunto que estava sendo abordado.

Por várias vezes declarou convictamente que era filho do sol e da lua que lhe davam total proteção e imunidade absoluta, inclusive contra a morte, para levar adiante sua missão de salvar o mundo das armas e das guerras. Dizia textualmente: La luna es mi mama y el sol es mi papa. Mi elegeran como su bijo en la tierra. Por isso, soy indestutible, porque tengo la protección del sol e de la luna.

Acreditava que possuía a missão de salvar a humanidade da guerra e por isso tinha que percorrer o mundo. Dizia-se um pacificador em busca do desarmamento e do desmascaramento de governantes gananciosos capazes de arruinar a humanidade. Dizia ainda, literalmente, que era o terceiro Cristo e que não o matariam, como haviam feito com o primeiro e o segundo. Em outro momento fez a seguinte afirmação: $A$ mi não me enlouquecessem, estoy sempre muy bien controlado.

É perceptível aqui a forte presença de uma persecutoriedade paranóide vivida como uma preocupação de que haveria pessoas interessadas em seu enlouquecimento ou em sua perda de controle. Tais inimigos estariam tramando contra sua missão e seriam capazes até de atentarem contra sua vida, como teria ocorrido com os Cristos anteriores a ele. Transparece também nesse caso um narcisismo bastante acentuado responsável pela inflação do Eu, pela consideração especial de si como alguém eleito por uma divindade ou forças sobrenaturais para conduzir um feito grandioso e pela auto-imputação de uma missão tão difícil e heróica na qual até Cristo teria fracassado.

Numa das entrevistas, o encontramos sentado em um banco improvisado com um pedaço de tronco de árvore, anotando as placas dos carros que passavam. Quando perguntamos sobre o sentido daquilo respondeu simplesmente: es mi trabajo. Logo a seguir, pegou uma folha de jornal que estava ao seu lado e começou a escrever, na parte de cima, a história do afundamento do Titanic. Seu texto dizia que em 1912 o Titanic fora afundado a mando do capitão Tupamaro, com milhões de dólares e matando mil pessoas. Ao terminar de escrever o texto tirou a carga da caneta, rolou sobre o polegar direito e colocou sua impressão digital como assinatura. Logo depois, queixou-se de que o mate que tomara há pouco - estava com uma latinha ao lado usada como copo - não lhe caíra bem. Contou ainda que reprocessava o pó de café e restos de mate já utilizados e jogados no lixo para fazer seu café e seu chá.

Quando questionado sobre a possibilidade ou o desejo de se fixar e desfrutar da companhia de uma mulher, nos disse ser aquela sua missão - de errante - e que uma vez finalizada teria todas as mulheres do mundo para si e, então, voltaria para a Argentina. O Sr. Felipe parecia contente e satisfeito com a vida que levava. Afirmou que não passava fome, que sempre recebia auxílio da população rural ou das cidades por onde passava. Não se queixou da sua condição e não mostrou maiores preocupações com o provimento das necessidades elementares. Mostrou-se, aliás, muito preocupado com sua missão e com os destinos do mundo.

Seu delírio de pacificador da terra a mando de seus pais e protetores o Sol e a Lua preenchia-o completamente e dava os sentidos e as realizações básicas de sua existência. Sentia-se útil e importante para a sociedade, considerando sua missão como o seu trabalho. Várias vezes afirmou que esse era seu trabalho ao qual se dedicava com afinco diariamente. Praticamente tudo que fazia durante o dia (anotar as placas dos carros que passavam pela rodovia, recortar matérias de revistas e jornais, escrever) atribuía às necessidades do seu trabalho e relacionava à sua missão.

Mostrava-se resignado com a tarefa que lhe fora atribuída, apesar dos sacrifícios que tinha que fazer para realizá-la. Afirmou, por exemplo, que não podia gozar da companhia feminina, que isso significaria cair em tentação e desviar-se de sua missão. Somente poderia ter uma mulher, ou melhor, todas, quando concluísse seu trabalho. Porém, mesmo um impedimento dessa ordem não parecia representar para ele um ônus insuportável. Ao contrário, dizia-se feliz e contente por ter sido escolhido para a referida missão e deixava transparecer um sentimento de orgulho e superioridade.

Pelo que pudemos compreender, parece um caso bem sucedido de encontro entre a errância e a loucura. Longe da vigilância e das pressões dos guardiões da razão, ele pode viver seus delírios sem perturbações externas e até mesmo com a admiração e atenção daqueles que, como nós, acabavam procurando contato e se interessando por sua epopéia. Nesse período em que permaneceu nas imediações da cidade de Marília foi visitado por jornalistas, assistentes sociais e pessoas curiosas em conhecê-lo. A polícia 
rodoviária também esteve lá exigindo sua transferência para um lugar mais seguro. Sr Felipe acabou abandonando o local e seguindo sua caminhada o que faria independentemente de qualquer pressão.

A condição de caminhante parece ter sido bem ajustada aos conteúdos dos seus delírios e ao sentido básico de sua vida. Nada mais apropriado do que andar pelo mundo para quem tem a missão de promover a paz no planeta e entre os povos. Nesse caso, é notável a presença de um delírio bastante fabulatório, imaginativo, megalomaníaco e paranóide centrado numa firme convicção de ter sido habitado por uma vontade superior que the conferiu qualidades especiais, como a imortalidade, um grande poder e a graça de realizar uma missão extraordinária.

Outro aspecto também bastante notável e significativo é a presença das figuras maternas e paternas nos delírios. Tanto o Sr. Felipe como Messias aludem a essas figuras colocando-as num lugar de destaque em suas fabulações. O primeiro fala do sol e da lua como seus genitores que lhe asseguram a máxima proteção e lhe dão poderes especiais, inclusive, a invulnerabilidade contra os ataques de inimigos e malfeitores. $O$ segundo atribui sua errância a uma necessidade incontrolável de procurar o pai desaparecido enigmaticamente, ainda na sua infância.

Ambos parecem profundamente marcados por um desamparo primevo, uma desfiliação originária que os teria desligado de vinculações psicossociais que fornecessem as bases para uma sedentarização. A remissão do desamparo primordial às figuras parentais torna-as catalisadoras de tantos outros desamparos e desfiliações vividos nas relações sociais mais amplas moduladas por um sistema sócio-econômico que aprofunda o individualismo, a competitividade extrema, o consumo, o endividamento, a volatilidade, a dispersão, a rarefação de vinculações estáveis e tantas outras condições que se amplificam ainda mais com a pobreza.

Não tendo cristalizado referências pessoais remetidas a um determinado território psicossocial, fomentador de uma identidade sedentária, buscam na errância ancoragens absolutas representadas pela figura de um pai supremo - Deus - que julgam poder um dia encontrar ou até mesmo assumir o seu lugar. A identidade sedentária, ou seja, representações de si remetidas a um determinado território psicossocial que permitem ao sujeito reconhecer-se como uma continuidade no tempo e no espaço, cede lugar a uma identidade nômade onde tal reconhecimento somente é possível na ruptura espaço-temporal onde o sujeito se vê como um errante em busca de alguma coisa.

Pode parecer paradoxal falar em "identidade nômade" uma vez que o conceito de identidade remete-se, dentro da tradição do pensamento moderno, à noção de permanência e unicidade, mesmo pressupondo-se a unidade dos contrários, conforme a lógica dialética, enquanto que o conceito de nomadismo vinculase às noções de mobilidade, transitoriedade e flutuação, típicas do pensamento pós-moderno que priorizaria os processos de subjetivação e não as questões de identidade (Signorini, 1998). A discussão aprofundada dessa questão foge aos propósitos desse artigo e nem está ao nosso alcance Queremos apenas registrar que entendemos uma presumível "identidade nômade" como a permanência de representações de si alusivas à movimentação e à errância.

Se antes havíamos afirmado que nada se repete na vida do andarilho, ao falarmos de sua labuta diária para sobreviver, é necessário não perder de vista que, obviamente, a errância ou a perambulação constitui a repetição matriz da subjetividade do andarilho e é exatamente por ela que ele se reconhece e identifica seus pares. Portanto, parece cabível falar em "identidade nômade" quando nos referimos a sujeitos que se reconhecem, fundamentalmente, como errantes que perambulam de um lugar a outro. É necessário ainda esclarecer que estamos utilizando o conceito de "identidade nômade" em referência apenas aos andarilhos, sem pretender estendê-lo para outras formas de nomadismo.

Retornando à análise dos delírios dos andarilhos como expressão radical da errância psicossocial, cabe ainda ponderar que, como pode ser apreendido nos três casos apresentados, a condição de caminhante, própria do andarilho, possibilita a vivência "real" de idéias delirantes premidas por fugas persecutórias, deserções de confinamentos e sedentarismos opressivos e produtores de sofrimentos psíquicos insuportáveis, desfiliações sócio-afetivas e tantos outros dispositivos contemporâneos de produção de desenraizamentos e movimentação.

Messias não compara, simbolicamente, sua condição de errante com a de Cristo carregando a cruz. Ele transpõe o limite entre o "Eu" e o "Outro", vivendo imaginariamente sua relação com Cristo acreditando que, como andarilho, conquistará a beatitude. Sr. Felipe, da mesma forma, acredita ser o terceiro Cristo enviado a Terra para, com suas perambulações, disseminar o espírito de paz e evitar a guerra e a destruição da humanidade.

Trata-se de encontros radicais entre delírios e errâncias onde idéias imaginárias, gestadas num estado de debilidade das funções egóicas de diferenciação Eu-Outro ou Sujeito-Mundo, se deparam na errância com possibilidades de expressão ampla e radical tanto pelas práticas do cotidiano do andarilho como pelo seu distanciamentos dos agentes e dos mecanismos de controle social da loucura.

Se a condição de andarilho-errante e as idéias delirantes retroalimentam-se, estabelecendo uma forte parceria, não é certo, entretanto, que sejam companheiras inseparáveis. Nem toda errância ou todo andarilho está fadado a produzir delírios como atestam os muitos casos de andarilhos que não manifestam sequer idéias deliróides como aquelas que acometem os sedentaristas em suas visões e crenças religiosas, por exemplo. Por outro lado, os sedentaristas estão sujeitos não apenas a idéias deliróides, como também, a delírios mais radicais como atestam as psicoses deflagradas em estados de fixação do sujeito. É claro que a errância psicológica, típica das psicoses, como enfatiza Calligaris (1989), pode acontecer independentemente de uma errância geográfica, assim como uma organização psicológica centralizada ou sedentarizada, típica da neurose, também acomete caminhantes contumazes.

A questão, em primeiro lugar, diz respeito à maneira como é subjetivada uma condição de maior ou menor fixação a um território psicossocial e geográfico. Tanto uma condição de estacionamento absoluto pode ser significada como desprendimentos de vinculações, como uma condição de movimentação constante pode ser subjetivada 
como um aprisionamento a uma compulsão para a caminhada, por exemplo.

Em segundo lugar, as esferas que diferenciamos na constituição do sujeito, como a psicológica, social, geográfica, cultural e assim por diante, não se interligam mecânica e automaticamente. Por exemplo, uma errância geográfica pode se contrapor a um sedentarismo psicológico como ocorre com viajantes que se aferram a determinadas idéias, crenças e vínculos afetivo-emocionais.

Nos casos que trouxemos aqui para discutirmos as relações entre errância e delírio estamos convencidos de que retratam sujeitos nos quais a errância se expressa de forma radical atravessando-os em todos os planos de sua constituição.

\section{Conclusão}

A condição de viver em movimento, a provisoriedade de cada momento do cotidiano, o afastamento de referenciais fixos e estáveis e o distanciamento dos marcos de sua história e origem expõem o andarilho a uma possibilidade de desestabilização total de seu Eu lançando-o na errância psíquica típica dos estados psicóticos. Tal condição de errante, embora vivida de forma radical pelos andarilhos, parece não ser exclusiva deles estando sendo disseminada hoje, progressivamente, por todo o corpo social.

O mundo contemporâneo, comprimindo cada vez mais o tempo e o espaço, tende a mergulhar o sujeito numa situação de constantes movimentações psicossociais e geográficas, expondo-o a uma experiência bem próxima da psicose. Tanto os considerados "loucos", como os "não loucos", são todos desalojados dos "lugares" para os "não-lugares", vivendo a errância como um trânsito constante de um lugar a outro.

O fenômeno da migração é o mais conhecido e estudado dentro dos deslocamentos de populações produzidos pelas exigências de movimentação ao longo da história. A figura do estrangeiro e do viajante, desde a antiguidade, tem seu lugar no imaginário social e operou como força considerável na dinamização da economia, da política e da cultura.

$\mathrm{Na}$ psicologia clínica, o migrante invariavelmente aparece como mensageiro do sofrimento psíquico disparado pela mudança abrupta e radical do cenário do cotidiano. O choque de realidades culturais distintas e o efeito de estranhamento de si mesmo produzido nessa situação são importantes disparadores de surtos psicóticos (Ferreira, 1998). Mas é no andarilho que as forças dromológicas da sociedade contemporânea operam com toda sua potência, produzindo um sujeito errante por excelência, nômade ao extremo que rompe com o sedentarismo e com qualquer outra forma de estabilização e vinculação psicossocial para viver uma caminhada sem destino ou ponto de chegada.

Diferentemente do migrante, o andarilho vive o choque de despersonalização e perda de identidade não apenas quando migra, mas também quando deixa de migrar, quando se vê na mesmice, parado, sem movimento, sem a possibilidade de se deslocar. No seu universo não existe o "outro", o espelho no qual pode se mirar e colher sua imagem, um outro que represente a diferença cobiçada. $\mathrm{O}$ andarilho não se choca porque não se confronta, se isola, desinveste o mundo recolhendo-se na solidão do "trecho". É o sujeito adaptado à dinâmica da atualidade. Vive sem raízes, sem memória, sem saudades do passado ou da terra natal, sem ilusão de progresso ou de melhoria na sua vida, solitário, imediatista, individualista e, sobretudo, errante.

Fugindo dos aprisionamentos do sedentarismo e navegando solitário e sem rumo, torna-se morada privilegiada de delírios constituídos na deserção ou num "lugar de fora" de percursos sociais, afetivos e cognitivos sulcados na lógica psicossocial dominante. $\mathrm{O}$ delírio pode ser compreendido como expressão de um movimento do pensamento ou da percepção que escapa de um eixo central de referência da subjetividade, um significante central em torno do qual se organizariam as demais significações. Analogamente, os andarilhos também escapam de um lugar identitário - um círculo psicossocial e geográfico no qual se encerra a subjetividade sedentária - para vagar no amplo horizonte de uma subjetividade sem raízes, sem fronteiras, em pleno movimento e sem fixações: uma subjetividade errante, nômade.

Entretanto, se no momento de ruptura com o sedentarismo o andarilho vive intensamente essa libertação das forças de gravitação que o enclausuravam num determinado círculo geográfico e psicossocial, acaba também sendo prisioneiro da errância, das forças que o impulsionam às constantes e intermináveis caminhadas. Depois de um tempo de estrada, entre idas e vindas, vacilações, tentativas de retorno ao sedentarismo e, sobretudo, depois de enfrentar as angústias e os sofrimentos das condições de vida como andarilho, passa a assumir a identidade de errante, incorporando completamente o desejo de perambular e o temor de qualquer tipo de fixação como constituintes fundamentais de sua pessoa.

As idéias delirantes, quando irrompem, expressam exatamente a vivência da errância. Primeiro, tais idéias abandonam qualquer lógica ou exame crítico convencional, ou os cativeiros da razão sedentária, e passam a buscar a compreensão de si mesmo e do seu mundo em percepções, representações e conexões mais voláteis e fugidias que escapam de enquadramentos e corredores associativos constituintes da "normalidade cognitiva". Segundo, os conteúdos das idéias delirantes denunciam os conflitos e os sofrimentos próprios da errância ou potencializados por ela.

Os estados maníaco-depressivos são claramente observáveis nos andarilhos. As intensas queixas de sofrimentos e frustrações vividos no gregarismo sedentário, a renúncia à convivência com o "outro", a solidão e o não estabelecimento de vínculos na errância denotam a reação de distanciamento do "mundo" diante de perdas e fracassos experimentados nos planos mais elementares da vida. No plano econômico, a pobreza e o desemprego aparecem como as principais experiências de fracasso. No plano afetivo, é a morte ou o desaparecimento dos pais e as traições conjugais ou a retirada do amor que aparecem como as grandes perdas e decepções com o mundo.

A contraface do retraimento depressivo é constituída pelos delírios megalomaníacos. As idéias engrandecedoras são compreensíveis como reação ou defesa contra o estado de indigência econômico-social, sofrimento e penúria afetiva que acometem o andarilho. As idéias messiânicas das quais se julgam portadores e as missões grandiosas que se auto-imputam nos delírios são poderosos 
sedativos para as angústias e os sofrimentos vividos no desamparo e na extrema solidão. As imagens que criam de si como "heróis" que conseguiram se lançar à realização de uma missão profética ou mesmo aquelas imagens mais suavizadas em que se retratam como destemidos desbravadores de caminhos desconhecidos em busca de um sonho de liberdade indicam a tentativa maníaca de compensar as imagens de impotência, miserabilidade e fracasso que se doam fartamente para a percepção de si mesmo e de seu mundo.

A paranóia é outro dinamismo bastante visível nos delírios dos andarilhos. A persecutoriedade aparece com bastante freqüência sob a forma de imagens e idéias que denotam temores, perigos e ameaças que rondam suas mentes. $O$ engrandecimento narcisista que infla $\mathrm{o}$ "Eu", permitindo ao sujeito visualizar-se como um grande personagem da história da humanidade, portador de uma missão megalomaníaca, acaba por trazer, em contrapartida, também a reconversão da hostilidade projetada no mundo, colocando o próprio sujeito como centro da ira ou de tramas de adversários. No mínimo, aparece nos delírios paranóides a suspeita de que inimigos ocultos estão tentando solapar a missão megalomaníaca para impedir a realização da grande obra, como acontece com o Sr. Felipe.

A persecutoriedade é companheira inseparável dos andarilhos, seja em grau elevado, fomentando delírios ou atuando de forma mais amena despertando sentimentos de desconflança e atitudes de suspeita e distanciamento dos outros. O "trecho" é visto como um "mundo selvagem", sem regras, sem proteção ou garantias coletivas de qualquer natureza. De fato, caminhando sozinhos pelos acostamentos das rodovias estão completamente expostos às mazelas da natureza e à arbitrariedade daqueles que se impõem como donos da estrada, essa "terra de ninguém". Soma-se à percepção dos perigos da estrada, a irrupção dos fantasmas de hostilidades vividas nas experiências afetivas primevas, tornando o mundo do andarilho prenhe de temores e alertas, sinalizando a abundância de adversidades.

A mobilidade extrema, a solidão, a volatilidade das referências identitárias e o esmaecimento do Outro potencializam movimentações psicológicas de cunho nômade e errante possibilitando a eclosão de idéias delirantes com as quais o andarilho apreende e representa ele mesmo e o seu mundo. Seja qual for o delírio, mesmo sendo tomado como uma visão e compreensão da realidade que salta das percepções, dos raciocínios e das lógicas dominantes, é necessário decodificá-lo em sua própria lógica, em seus percursos associativos e em seus processos de representação e simbolização para apreendermos os sentidos da inteligibilidade do mundo que produz.

Os desvarios delirantes dos andarilhos, devidamente compreendidos nos processos psicossociais que os constituem, expressam de forma contundente e radical a vivência cruel das formas de aprisionamento, controle e sujeição no sedentarismo e na errância. Mais do que isso, os delírios dos andarilhos podem ser tomados também como expressões de uma vivência extrema das condições de vida presentes na sociedade contemporânea e, nesse sentido, podem ser compreendidos como espelhamento da vida atual.

\section{Referências}

Calligaris, C. (1989). Introdução a uma clínica diferencial das psicoses. Porto Alegre: Artes Médicas.

Castel, R. (1994). Da indigência à exclusão, a desfiliação. Em A. Lancetti (Org.), Saúdeloucura (Vo. IV; pp. 21-48). São Paulo: Hucitec.

Castel, R. (1998). As metamorfoses da questão social (I. D. Poleti, Trad.). Petrópolis, RJ: Vozes. (Original publicado em 1995)

Ferreira, A. P. (1998). Migração: Desdobramentos subjetivos e alternativos. Cadernos de Psicologia, 8, 97-115.

Ferreira, A. P. (1999). O migrante na rede do outro: Ensaios sobre alteridade e subjetividade. Rio de Janeiro: TeCorá.

Jacques, M. G. C. (1998). Identidade e trabalho: Uma associação indispensável. Em A. Tamayo, J. E. B. Andrade \& W. Codo (Orgs.), Trabalho, organiz̧ação e cultura (pp. 41-47). São Paulo: Cooperativa de Autores Associados.

Justo, J. S. (1998). Errâncias e errantes: Um estudo sobre os andarilhos de estrada. Em J. S. Justo \& R. Y. Sagawa (Orgs.), Rumos do saber psicológico (pp. 125-139). São Paulo: Arte \& Ciência.

Justo, J. S. (2000). Saúde mental em trânsito: Loucura e a condição de itinerância na sociedade contemporânea. Em M. L. Boarini (Org.), Desafios na atenção à saúde mental (pp. 09-29). Maringá, PR: Eduem.

Melo, A. L. N. (1979). Psiquiatria. Rio de Janeiro: Civilização Brasileira.

Nascimento, E. C. \& Justo, J. S. (2000). Vidas errantes e alcoolismo: Uma questão social. Psicologia: Reflexão e Crítica,13, 529-538.

Signorini, I. (1998). Figuras e modelos contemporâneos da subjetividade. Em I. Signorini (Org.), Lingua(gem) e identidade (pp. 333-380). Campinas, SP: Mercado das Letras/ Fapesp.

Singer, P. (1999). Globalização e desemprego: Diagnóstico e alternativas. São Paulo: Contexto. Snow, D. \& Anderson, L (1998). Desafortunados: Um estudo sobre o povo da rua. (S. Vasconcelos, Trad.). Petrópolis, RJ: Vozes (Original publicado em 1992)

Recebido: 07/11/2003

$1^{a}$ Revisão: 26/02/2004

Aceite Final: 14/04/2004

Sobre os autores

José Sterza Justo é Doutor em Psicologia Social pela Pontifícia Universidade Católica de São Paulo. É Docente nos Cursos de Graduação e PósGraduação em Psicologia da Universidade Estadual Paulista, campus Assis, onde é Integrante do Grupo de Pesquisa: Psicologia e Instituições.

Eurípedes Costa do Nascimento é Psicólogo e Mestre em Psicologia pela Universidade Estadual Paulista, Campus Assis, onde é integrante do Grupo de Pesquisa Psicologia e Instituições. Foi bolsista Capes. 